\title{
PARTISIPASI KELOMPOK SADAR WISATA DALAM PENGEMBANGAN PARIWISATA HALAL DI DESA SESAOT KECAMATAN NARMADA KABUPATEN LOMBOK BARAT
}

\author{
Hermanto', Siti Nurmayanti², Lalu Ferdi Ferdiansyah ${ }^{3}$, Lalu Gde \\ Muhamad Subhan ${ }^{4}$, Muhammad Ma'ruf ${ }^{5}$, Noni Antika \\ Khairunnisah ${ }^{6}$, Vina Ayu Hidayati ${ }^{7}$ \\ 1,2Faculty of Economics and Business, Mataram University, Indonesi \\ 3,4,5,6,7 Master of Management Program, Mataram University, Indonesia. \\ E-mail: ferdiferdiansyahlalu@gmail.com
}

\section{ARTICLE INFO}

Keywords :

Considered Tourist Group Participation, Halal Tourism Development, Sesaot Village.

Kata Kunci:

Partisipasi Kelompok Sadar Wisata, Pengembangan Pariwisata Halal, Desa Sesaot

How to cite :

Hermanto., Nurmayanti, Siti., Ferdiansyah, Lalu Ferdi., Subhan, Lalu Gde Muhamad., Ma'ruf, Muhammad., Khairunnisah, Noni Antika., Hidayati, Vina Ayu., (2020). Partisipasi Kelompok Sadar Wisata Dalam Pengembangan Pariwisata Halal Di Desa Sesaot Kecamatan Narmada Kabupaten Lombok Barat. JMM UNRAM, 9(4), 383-388

DOI :

http://dx.doi.org/10.29303/jmm.v9i4.594

$\begin{array}{ll}\text { Dikumpulkan } & : 20 \text { Oktober } 2020 \\ \text { Direvisi } & : 19 \text { November } 2020 \\ \text { Dipublikasi } & : 04 \text { Desember } 2020\end{array}$

\section{ABSTRACT}

This research is qualitative and quantitave research of Considered Tourist Group Participation of Halal Tourism Development at Sesaot Village, Narmada, West Nusa Tenggara. The result of research shows that the Tourist Group Participation is enthusiast, seen from the initiative of Tourist Group, destination managerial, empowerment and community participation. There two factors in this research such as supporting and inhibiting factors. The supporting factor is obtanied from outside they are natural resources, the role and support of the government and the involvement of Tourist Group which is the sustainable tourism observatory (STO), the driving force and support for Tourist Group to develop and exploit their tourism potential at Sesaot village. Currently, Sesaot tourism is already reached of utilizing the results. While, the inhibiting factors is the lack of understanding and knowledge of Tourist Group about tourism and the lack of funds.

Penelitian ini merupakan penelitian kualitatif deskriptif yang membahas tentang partisipasi kelompok sadar wisata dalam pengembangan pariwisata halal di desa sesaot kecamatan Narmada kabupaten Lombok barat. Hasil penelitian ini menunjukkan bahwa partisipasi Pokdarwis didesa sesaot sangat besar dilihat dari inisiatif pembentukan Pokdarwis, manajerial destinasi, pemberdayaan maupun partisipasi masyarakat. Terdapat dua factor yang terdapat pada penelitian ini adalah pertama factor pendukung dan kedua factor penghambat. Adapun factor pendukung yaitu terdapat motivasi yang diperoleh dari luar seperti halnya sumber daya alam, peran dan dukungan pihak pemerintah serta keterlibatan organisasi anggota pokdarwis salah satunya adalah sustainable tourism observatory (STO), turut menjadi 
penggerak dan pendukung anggota pokdarwis untuk terus berpacu mengembangkan dan memanfaatkan potensi wisata di desa sesaot. Sehingga wisata Sesaot saat ini sudah sampai pada tahap pemanfaatan hasil. Sedangkan factor penghambat pada penelitian ini adalah Lemahnya pemahaman dan pengetahuan anggota Pokdarwis mengenai pariwisata serta kurangnya dana membuat anggotanya belum maksimal dalam berpartisipasi.

Copyright (c) 2020. Hermanto, Siti Nurmayanti, Lalu Ferdi Ferdiansyah, Lalu Gde Muhamad Subhan, Muhammad Ma'ruf, Noni Antika Khairunnisah, Vina Ayu Hidayati. All rights reserved.

\section{PENDAHULUAN}

\subsection{Partisipasi}

Menurut (Bessette, 2004) partisipatif adalah suatu aktivitas yang melibatjan proses partisipasi dalam satu sisi dan memanfaatkan media komunikasi interpersonal untuk dapat memfasilitasi dialog yang terjadi antara pihak yang menjadi pemangku kepantingan yang berbeda-beda dan berkisar pada rumusan masalah yang menjadi sasaran pembangunan bersama-sama serta pengembangan dan pelaksanaan aktivitas yang telah disepakati bersama untuk berkontribusi mencari solusi yang didukung bersama.

\subsection{Kelompok sadar wisata}

Menurut (Yatama, 2019) Kelompok sadar wisata adalah suatu kondisi yang menggambarkan partisipasi dan dukungan segenap komponen masyarakat dalam mendorong terwujudnya iklmi yang kondusif bagi tumbuh dan berkembangnya kepariwisataan di suatu destinasi atau daerah. Sedangkan sapta pesona adalah jabaran konsep sadar wisata terkait dengan dukungan dan peran masyarakat sebagai tuan rumah dalam upaya untuk menciptakan lingkungan dan suasana kondusif yang mampu mendorong tumbuh dan kembang industry pasriwisata melalui perwujudan unsur aman tertib, bersih, sejuk, indah, ramah unsur kenangan (Rahim, 2012). Menurut (Kementrian, 2015) Munculnya istilah halal tourism atau pariwisata halal pada awalnya suatu kegiatan yang dilakukan oleh wisatawan atas dasar untuk menumbuhkan motivasi rasa atau nilai religi yang ada dalam dirinya dengan mengunjungi tempat-tempat ibadah, tempat pemakaman, atau tempat bersejarah yang memiliki nilai-nilai religi sesuatu dengan agama yang dianut. Pada awalnya pariwisata ini disebut juga dengan wisata religi

\subsection{Pariwisata Halal}

Fundamental dari wisata Syariah tentunya adalah pemahaman makna halal disegala aspek kegiatan wisata mulai dari hotel, sarana transprtasi, sarana makanan dan minuman, system keuangan, hingga fasilitas dan penyedia jasa wisata itu sendiri. Sebagai contoh hotel Syariah tidak akan menerima pasangan tamu yang akan menginap jika tamu tersebut merupakan pasangan yang bukan muhrimnya (tidak dapat menunjukkan surat nikah). Selain itu hotel yang mengusung konsep Syariah tentunya tidak akan menjual minuman beralkhohol serta makanan yang mengandung daging babi yang diharamkan didalam islam. Selain itu pemilihan destinasi wisata yang mengandung nilai-nilai Syariah islam juga menjadi pertimbangan utama dalam mengaplikasikan konsep wisata Syariah, setiap destinasi wisata yang dituju haruslah sesuai dengan nilai-nilai keislaman seperti 
memiliki fasilitas ibadah masjid atau mushola yang memadai, tidak adanya tempat kegiatan hiburan malam serta prostitusi dan juga masyarakat mendukung implementasi nilai-nilai Syariah islam seperti tidak adanya perjudian, sabung ayam maupun ritual-ritual yang bertentangan dengan ajaran islam (Kovjanic, 2014).

Menurut (Lestari, Fitra, \& Budi, 2019) Produk halal yang didistribusikan dengan pengawasan untuk jaminan kualitas pasar, memiliki tujuan memberikan kepastian dan keyakinan kepada pembeli untuk menggunakan produk dengan dasar sertifikat halal yang ditunjukkan label yang tertera di produk. Produk halal yang telah memiliki sertifikat memberikan jaminan bahwa proses produksi dan pelibatan sumber bahan baku telah melalui verifikasi oleh Lembaga Independen yang melaksanakan proses berdasarkan sistem syariah

\section{METODE PENELITIAN}

\subsection{Jenis Penelitian}

Penelitian ini menggunakan jenis penelitian kualitatif deskriptif. Pada penelitian kualitatif deskriptif ini peneliti berusaha menggambarkan kegiatan penelitian yang dilakukan pada obyek tertentu secara jelas dan sistematis.Penelitian ini bermaksud untuk memahami fenomena tentang apa yang dialami oleh subyek penelitian misalnya perilaku, presepsi, motivasi, tindakan dan lain-lain, dan dengan cara deskripsi dalam bentuk katakata dan bahasa, pada suatu konteks khusus yang alamiah dan dengan memanfaatkan berbagai metode alamiah (Moleong, 2014)

\subsection{Tahap-Tahap Penelitian}

Tahapan-tahapan Penelitian ini dilakukan dengan cara :

a. Observasi

Observasi adalah metode menganalisis dan membuat catatan secara sistematis atau langsung di lapangan, peneliti mendapatkan gambaran yang lebih luas tentang permasalahan yang diamati. Observasi yang dilakukan dengan cara melihat langsung bentuk partisipasi Pokdarwis dalam pengembangan pariwisata halal di Desa Sesaot.

b. Wawancara

Wawancara merupakan teknik pengumpulan data yang dilakukan dengan bertanya langsung kepada informan yang berkaitan dengan data yang dibutuhkan. Wawancara dilakukan untuk mengumpulkan data secara menyeluruh atau mendalam dari beberapa pihak atau anggota Pokdarwis yang terlibat langsung di Desa Sesaot.

c. Dokumentasi

Dokumentasi merupakan pengumpulan data dengan menggunakan sumbersumber dokumentasi baik berupa foto, atau dokumen yang berhubungan dengan pengembangan pariwisata halal di Desa Sesaot.

\subsection{Deskripsi Latar, Sumber Data, Epistemologi}

Penelitian ini dilaksanakan di Desa Sesaot, Kecamatan Narmada, Kabupaten Lombok Barat, Nusa Tenggara Barat tahun 2018 berkaitan dengan partisipasi kelompok sadar wisata (Pokdarwis) dalam pengembangan pariwisata halal di Desa Sesaot.Jenis data di dalam penelitian ini adalah data kualitatif kata-kata, kalimat dan gambar atau foto yang diperoleh selama proses pengamatan di lapangan atau berbagai informasi dan keterangan yang diperoleh langsung dari sumbernya, seperti para pihak yang dijadikan informan penelitian. Data sekunder yang dilakukan dalam penelitian ini dengan berbagai teori dan informasi yang diperoleh tidak langsung dari sumbernya, yaitu dari Menurut Meleong 
(2011) yaitu sumber data utama dalam penelitian ini adalah foto yang didapatkan selama proses penelitian dilakukan, foto-foto, buku, laporan penelitian, media informasi, dan media lainnya.

Peneliti melakukan wawancara dengan membuat janji terlebih dulu dengan informan kepala desa Sesaot, ketua pokdarwis, dan anggota Pokdarwis mengenai waktu yang lebih tepat untuk memberikan informasi. Peneliti menginformasikan bahwa setiap pembicaraan akan didokumentasikan dalam bentuk foto maupun rekaman. Proses dokumentasi dilakukan setelah mendapat persetujuan dari informan.

\subsection{Teknik dan Alat Pengumpulan Data}

\subsubsection{Teknik Pengumpulan Data}

Teknik pengumpulan data dalam penelitian ini adalah:

i) Observasi dalam penelitian ini melakukan pengamatan fenomena yang terjadi terkait dengan pengembangan pariwisata halal di Desa Sesaot.

ii) Wawancara yaitu tanya jawab secara langsung mengenai pengembangan pariwisata halal di Desa Sesaot. di Lombok Barat Nusa Tenggara Barat yang berkaitan dengan penelitian.

iii) Dokumentasi yaitu pengumpulan data dari sumber-sumber jurnal dan buku.

\subsubsection{Alat Pengumpulan Data}

Alat pengumpulan data dalam rencana penelitian ini adalah:

i) Alat perekam untu membantu peneliti mengingat detail dari wawancara

ii) Alat tulis, dan buku tulis digunakan untuk dokumentasi dalam mencatat hasil wawancara. Kamera digunakan untuk mendapatkan foto untuk dokumentasi. Laptop dIgunakan sebagai bahan mencari jurnal atau dokumen mengenai pengembangan pariwisata halal di Desa Sesaot.

\subsection{Analisis dan Penafsiran Data}

Analisis data merupakan upaya mencari dan menata secara sistematis catatan hasil observasi, dokumentasi dan wawancara, untuk meningkatkan pemahaman penelitian tentang kasusyang diteliti dan menyajikan sebagai temuan orang lain (Gunawan, 2013). Metodeanalisis yang digunakan adalah menggunakan pendekatanDeskriptif Kualitatif. Deskriptif kualitatif adalah memberikanpredikat kepada variable yang diteliti sesuai dengan kondisi yangsebenarnya, yaitu dengan cara memaparkan informasi-informasiyang akurat yang diperoleh dari ketua pokdarwis, kepala desa Sesaot, dan masyarakat yang terlibat juga ikut merasakannya.

\section{HASIL DAN PEMBAHASAN}

\subsection{Fungsi dan Peran Pokdarwis}

Berdasarkan hasil wawancara dengan interviewer terpilih, Pokdarwis Desa Sesaot memiliki peran dan fungsi sebagai berikut:

1. Penggagas Desa Wisata

Berdasarkan keterangan dari ketua Pokdarwis yaitu Pak Jabot, penggagas berdirinya desa wisata sesaot adalah anggota pokdarwis sendiri. Didorongnya Desa Sesaot menjadi desa wisata yaitu tahun 1996 namun wisatawan mulai berdatangan pada tahun 2004 dan mendapatkan izin menjadi desa wisata yaitu tahun 2008.

2. Manajerial destinasi 
Peran dan fungsi Pokdarwis sebagai manajerial destinasi ini maksudnya yaitu melakukan perencanaan, mengawasi pelaksanaan, mengontrol, melaksanakan, mengembangkan destinasi, dan mengevaluasi semua kegiatan yang sudah terlaksana.

3. Pemberdayaan Masyarakat.

Berdasarkan hasil wawancara, kesuksesan destinasi-destinasi yang dikembangkan sangat didukung oleh bagaimana support masyarakat sekitar terhadap destinasi-destinasi tersebut. Oleh karena itu Pokdarwis Sesaot secara aktif melakukan pemberdayaan masyarakat sekitar dengan mengadakan workshop dan pelatihan-pelatihan yang mendukung destinasi-destinasi tersebut.

4. Mensosialisasikan desa wisata halal kemasyarakat.

Berdasarkan keterangan dari responden terpilih, pokdarwis senantiasa aktif dalam mensosialisasikan konsep desa wisata kemasyarakat melalui peringatan hari-hari besar islam seperti peringatan Maulid Nabi Muhammad SAW, Peringatan Isra' Mi'raj, Idul Fitri, Idul Adha, dan lain sebagainya.

5. Mempertahankan kearifan lokal Desa Sesaot.

Berdasarkan keterangan dari responden terpilih, Desa wisata sesaot sampai saat ini masih dikenal sebagai desa yang mampu mempertahankan dan melestarikan kearipan lokal masyarakatnya seperti adat istiadat dan awik-awiknya.

\subsection{Bentuk Partisipasi Pokdarwis Di Desa Sesaot}

Bentuk partisipasi Pokdarwis yang dimaksud adalah berbagai program atau kegiatan yang akan dilakukan untuk mewujudkan fungsi dan tujuan Pokdarwis. Adapun kegiatan-kegiatan yang dilakukan oleh anggota Pokdarwis di Desa Sesaot adalah memberikan pelayanan informasi kepada wisatawan, memberikan masukan kepada aparat pemerintah, share knowledge ke anggota-anggota Pokdarwis untuk meningkatkan pemahaman dan wawasan para anggota Pokdarwis mengenai kepariwisataan, mempromosikan dan mensuport kegiatan-kegiatan untuk mempertahankan kearifan lokal di Sesaot, mensosialisasikan dan memotivasi masyarakat agar menjadi tuan rumah yang baik untuk mendukung kegiatan kepariwisataan, serta memotivasi masyarakat untuk mempertahankan dan meningkatkan kualitas lingkungan baik alam maupun budaya sehingga menjadi daya tarik pariwisata di Desa Sesaot.

\subsection{Faktor Pendukung dan Penghambat Peran Pokdarwis Di Sesaot}

\section{Faktor Pendukung}

Faktor pendukung utama tebentuknya pokdarwis di desa Sesaot adalah sumber daya alam yang menjadi potensi wisata. Selanjutnya adalah ada dukungan dan peran pemerintah baik tingkat Kepala Desa maupun Pemerintahan Kabupaten yang memfasilitasi baik dari pelatihan pokdarwis, kegiatan-kegiatan untuk pengembangan pariwisata, dan pembentukan badan hukum seperti SK untuk Pokdarwis. Serta keterlibatan organisasi seperti Sustainable Tourism Observatory (STO) turut menjadi penggerak dan pendukung anggota pokdarwis dari segi akademisi dalam mengembangkan dan memanfaatkan potensi wisata di Desa Sesaot.

2. Faktor Penghambat

Faktor penghambat partisipasi Pokdarwis adalah lemahnya pemahaman dan pengetahuan anggota Pokdarwis mengenai pariwisata. Faktor kedua adalah keterbatasan dana, sehingga menyebabkan anggota Pokdarwis menjadi malas untuk berpartisipasi. Faktor ketiga yaitu kurangnya dukungan dari tokoh-tokoh masyarakat (tertua) terhadapat pengembangan pariwisata halal.Faktor terakhir adalah terhambat dengan aturan aturan 
kecamatan dan daerah sehingga jadi faktor penghambat tingkat kecepatan inovasi pokdarwis sesaot.

\section{KESIMPULAN}

Bentuk partisipasi Pokdarwis yang dimaksud adalah berbagai program atau kegiatan yang akan dilakukan untuk mewujudkan fungsi dan tujuan Pokdarwis. Adapun kegiatan-kegiatan yang dilakukan oleh anggota Pokdarwis di Desa Sesaot adalah memberikan pelayanan informasi kepada wisatawan, memberikan masukan kepada aparat pemerintah, share knowledge ke anggota-anggota Pokdarwis untuk meningkatkan pemahaman dan wawasan para anggota Pokdarwis mengenai kepariwisataan, mempromosikan dan mensuport kegiatan-kegiatan untuk mempertahankan kearifan lokal di Sesaot, mensosialisasikan dan memotivasi masyarakat agar menjadi tuan rumah yang baik untuk mendukung kegiatan kepariwisataan, serta memotivasi masyarakat untuk mempertahankan dan meningkatkan kualitas lingkungan baik alam maupun budaya sehingga menjadi daya tarik.

\section{DAFTAR PUSTAKA}

Bessette, G. (2004). Involving the Community . A Guide to Participatory.

Gunawan, I. (2013). Metode penelitian kualitatif. Jakarta: Bumi Aksara, 143.

Kementrian, P. R. (2015). Laporan Akhir Kajian PengembanganWisata Syariah. Jakarta: Kementerian Pariwisata RI.

Kovjanic, G. (2014). Islamic Tourism as a Factor of the Middle East Regional Development. Lestari, Fitra, \& Budi, A. (2019). Strategi Rantai Pasok Halal di Malaysia.

Moleong, J. L. (2014). Metodologi Penelitian Kualitatif. Bandung: PT. Remaja Rosdakarya.

Rahim, F. (2012). Buku pedoman kelompok sadar wisata. Direktur jenderal pengembangan destinasi pariwisata kementrian pariwisata dan ekonomi kreatif.

Yatama, P. T. (2019). Efektivitas Pemberdayaan Masyarakat Oleh Kelompok Sadar Wisata (Pokdarwis) Dalam Mengembangkan Pariwisata Berkelanjutan (Studi pada Pokdarwis Minang Rua Bahari di Desa Kelawi, Kecamatan Bakauheni, Kabupaten Lampung Selatan). 